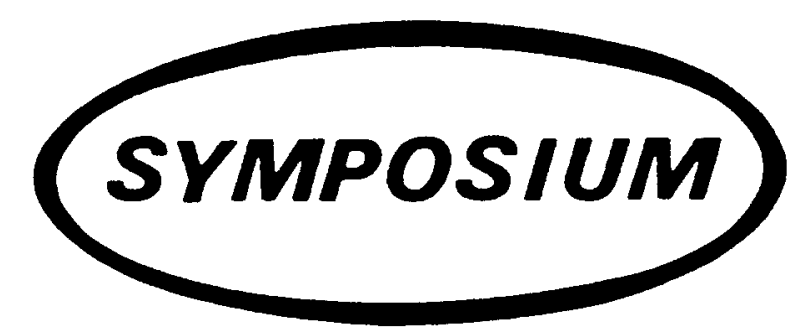

\title{
Sexing Geography, Teaching Sexualities [1]
}

KIM ENGLAND, University of Toronto, Canada

ABSTRACT I draw on my own experiences as a straight feminist geographer to address questions regarding teaching sexualities in geography. First, I look at 'sexing' and 'queering' geography curricula, not only upper level undergraduate and graduate courses that lend themselves to discussions of sexualities, compulsory heterosexuality, and heterosexism, but also lower level undergraduate courses. Second, a sexual dissident's first self-disclosure to another person typically takes place in college. As such, I discuss strategies that aim to make universities and classrooms less heterosexist and lesbolhomophobic. Finally, I discuss my dilemmas around the disclosure of my sexuality in the context of teaching.

KEYWORDS Curricula, inclusive language, safe spaces, panoptic gaze, self-disclosure.

If all space is closeted, then perhaps the space of the academy is among the most closeted of them all...(But) our classes are rarely (if ever) all straight, there is an affirmative and empowering side not only to being 'out' in the classroom, but in teaching about sexuality (Bell \& Valentine, 1995, pp. 24-25).

In this paper I want to address three sets of questions regarding teaching sexualities in geography as a straight feminist geographer. First, how have, and can geographers go about 'sexing' and 'queering' geography curricula? [2]. Second, how have, and can geographers go about 'sexing' (and 'queering') our classrooms, departments and universities? And, finally, what about 'sexing' the geographer?

\section{'Sexing' the Curriculum}

(Geography) has assumed a heterosexual norm and, in so doing, has obliterated alternatives and contributed to the non-examination of compulsory heterosexu- 


\section{SYMPOSIUM}

ality in geography. I see one of my own future tasks as more systematically assessing (the geography I teach) in terms of its heterosexism (Johnson, 1994, p. 110).

I began teaching about sexualities in the mid-1980s as a graduate student teaching 'Introduction to Women's Studies'. The material I was teaching was not inherently geographical, but it did open my eyes to the hegemony of compulsory heterosexuality in geographic research and teaching. However, once I became a geography professor, I found it a struggle to 'sex' geography curricula. As Peter Jackson (1989, p. 104) remarked: 'gender and sexuality (were) still too rarely regarded as part of the central agenda of human geography ... regarded as peripheral, private, and personal issues, not suitable for academic debate or public discussion ... What could possibly be geographical, critics imply, about such intimate personal subjects as gender and sexuality?" (emphasis in the original). Several years later, gender and sexuality are clearly part of the agenda of human geography. For example, in charting possible future research directions for Environment and Planning A, Nigel Thrift and Ron Johnston (1993, p. 89) argued that: "(i)n the 1980s, the main emphases were on issues of class, gender, and globalisation. In the 1990s, more emphasis will probably be placed on three areas of work. The first of these is sexuality and sexual politics".

The 1990s have seen a rapid expansion of published research on sexualities and sexual identities. Most major English language geography journals have published articles related to sexualities (although there are notable holdouts). There is certainly no longer a shortage of materials that can be used to teach the geographies of sexualities although there is a shortage of materials looking explicitly at heterosexualities. Important exceptions include Grant (1996, 1997), McDowell (1995) and McDowell and Court (1994a, 1994b). I have found David Bell and Gill Valentine's edited volume Mapping Desire (1995), and Bell (1991) particularly instructive in 'sexing' my curricula (also see the Arena Symposium on teaching sexual geographies in JGHE in 1997 with contributions by David Bell, Gill Valentine and Tracey Skelton).

Most of my teaching falls under the general rubric of urban, social and political geography. For the last 8 years I have taught an upper level undergraduate course entitled 'Women and the City' and a graduate seminar in social geography. Sexuality is one of the key themes in both these courses. The central points that I want to get across to the students are: (1) heterosexualities are taken-for-granted and naturalised; and (2) space and social identities (including sexualities) are mutually constructed. I illustrate these points by exposing the assumptions of universal heterosexuality in the planning and design of cities (I draw on Knopp (1992, 1995) and Valentine (1993b, 1995, 1996)). We look at examples of 'mapping' gay and lesbian communities (Castells, 1983; Winchester \& White, 1988; Jackson, 1989; Adler \& Brenner, 1992), consider the visibility of gay men in 'revitalising' inner cities (Lauria \& Knopp, 1985; Knopp, 1990; Bouthillette, 1994), and the less visible residential concentrations of lesbians (Adler \& Brenner, 1992; Peake, 1993; Rothenberg, 1995). We examine how gay men have engaged political structures to their territorial advantage (Jackson, 1989; Geltmaker, 1992; Brown, 1994, 1995; Davis, 1995; Forest, 1995) and explore lesbians' and gay men's efforts to negotiate and transform the heterosexism of everyday spaces (Valentine, 1993a,b, 1995, 1996; Knopp, 1994).

Of course, the character of these two particular courses lends itself to the inclusion of issues related to sexual identities, compulsory heterosexuality and heterosexism. A few years ago, I realised that I was 'ghettoising' sexualities into these specialised, 


\section{SYMPOSIUM}

upper level courses and might even be guilty of reinscribing sexualities as "peripheral, private, and personal issues, not suitable for academic debate or public discussion" (Jackson, 1989, p. 104). This also meant that I was not discussing sexualities with the majority of the students that I teach (and arguably, the more lesbo/homophobic and heterosexist students). So I have embarked on what I consider to be the more difficult task of revising my lower level courses to incorporate issues of sexualities. I try to be mindful of Louise Johnson's concerns about "the non-examination of compulsory heterosexuality in geography" (1994) and Gill Valentine's point that "(v)isibility across the curriculum is important for dissident sexualities because it normalises them" (1997, p. 421). In addition to lectures specifically on geographies of sexualities, I work hard at using inclusive language in all my lectures. For example, when talking about residential location choice models in my first year urban geography course, I might ask the students, "if you were straight and were looking for a home with your partner, what factors would be important?" I am attempting to be aware of the impacts of what Lisa Walker (1995, p. 73) describes as the "(hetero)gendered quality" of language.

\section{'Sexing' the University}

(T)he politics of the classroom all too often reinforce norms rather than bringing them into discussion...the classroom and a multitude of other sites (such as residence halls) offer pedagogic moments for learning and liberation if we use them for interpretation rather than the mere telling of the facts. (Rhoads, 1994, p. 107).

I am fortunate enough to teach at a university where there is an explicit anti-discriminatory and harassment policy that includes sexual orientation. So, for example, spousal benefits are fully available to same-sex partners and their families. There are also lesbian, gay and bisexual student organisations. In the spring of 1996, a committee of staff, faculty, and students concerned that the university continue as a lesbian and gay positive community, launched the 'Positive Space Campaign'. The committee encourages the university community to show their support by using stickers and posters of a rainbow triangle with the following statement, "LESBIAN AND GAY POSITIVE SPACE: This is a place where human rights are respected, and where gays, lesbians, bisexuals, their friends and allies are welcomed and supported". The aim of the campaign is that the stickers and posters will generate discussion about sexual diversity. In their pamphlet, the committee states:

The Campaign for Positive Space challenges the patterns of silence that still marginalise lesbians, gays and bisexuals, even in environments with anti-discriminatory and inclusive policies. Whether you are straight, lesbian, gay, or bisexual, putting a 'positive space' sticker on the door of your office, your residence room, your apartment, means that you are contributing to the creation of an environment that welcomes sexual diversity. It suggests that you are ready to respond favorably to those who may feel marginalised because of sexual orientation, or who themselves feel hesitant to speak out positively. It also suggests that you are prepared to challenge homophobic and stereotypical talk, even if it is said in jest. [3]

As a geographer, I was obviously struck by the spatiality of the strategy of the Campaign for Positive Space. In many ways the campaign is reminiscent of recent work by geographers that foregrounds the spatial constitution of sexual identities, and deals 
with destablising heterosexual spaces, and the 'queering' of everyday straight spaces. The campaign highlights ways in which space is not only central to the perpetuation of heterosexism and lesbo/homophobia, but is also crucial to struggles against heterosexism and lesbo/homophobia.

The campaign seeks to "challenge the patterns of silence that still marginalise lesbians, gays and bisexuals". This is reminiscent of Tim Davis' (1995) use of Foucault's concept of the panopticon as a metaphor for heterosexism. A panopticon is a spatial design for a prison that keeps inmates isolated from one another, but within constant view of their jailers (who are not visible to the inmates). The inmates engage in self-monitoring and isolate themselves, even when their jailers are not present. Thus, the panoptic heterosexist gaze encourages self-monitoring and serves to isolate and silence lesbians, gay men and bisexuals. The closet provides a degree of insulation and safety from heterosexism and lesbo/homophobic prejudice, but managing a sexual identity that is not your own is stressful and "the closet is not a place to develop a positive sense of identity" (Rhoads, 1994, p. 74; see also Valentine (1993b)).

The hegemony of heterosexual assumption means that coming out is a lifelong process. However, the first self-disclosure to another person typically takes place in college, although self-acknowledgement usually occurs earlier (D'Augelli, 1989; Rhoads, 1994). Surveys at a number of US universities indicate high rates of victimisation among lesbian and gay students (and faculty) who are out. They face far higher rates of discrimination, intimidation and harassment than straight students (and faculty). Between one-half and three-quarters of respondents report being verbally harassed, between one-quarter and one-half report that they have been threatened with physical violence (D'Augelli, 1989; Rhoads, 1994; Valentine, 1997). Recent US estimates suggest that 30 per cent of suicides of women and men aged 15 to 24 years are related to turmoil over their sexuality, and that young lesbians, gay men and bisexuals are twice as likely to commit suicide as their straight counterparts (Wright, 1993).

In many instances, faculty and students unwittingly discuss the experiences of themselves and their peers as if everyone is heterosexual. Other lives are excluded from discussions and not represented in the classroom. In so doing, structures of domination and oppression are reinforced. Lesbians, gay men and bisexuals are marginalised and silenced. Rhoads points out that "(s)ilencing tactics revolve around power-who controls discourse, who defines truth, who determines what knowledge is relevant or irrelevant, who speaks, who listens" (1994, p. 110). Teresa de Lauretis encourages "all feminist scholars and teachers (to work in the) spaces in the margins of hegemonic discourses, social spaces carved in the interstices of institutions and in the chinks and cracks of the power-knowledge apparati" (de Lauretis, 1987, p. 25). Certainly 'sexing' curricula relates not only to what we teach, but also how we teach. Teaching against lesbo/homophobia and heterosexism is hard work, professionally and emotionally. Heterosexuality is taken for granted and naturalised. Heterosexism and lesbo/homophobia are internalised. Rhoads laments that "the politics of the classroom all too often reinforce norms rather than bringing them into discussion", but reminds us that the classroom provides opportunities for "pedagogic moments for learning and liberation". And taking advantage of these opportunities can become what Teresa de Lauretis describes as "the micropolitical practices of daily life and daily resistances that afford both agency and sources of power or empowering investments" (de Lauretis, 1987, p. 25). 


\section{SYMPOSIUM}

\section{'Sexing' this Geographer}

Providing models of gay/lesbian teachers is important for both gay/lesbian students and for heterosexual students. It helps to break the sense of isolation, hopelessness, and fear experienced by gay and lesbian students...For heterosexual students, the presence of an openly gay or lesbian teacher can provide them with an important model, too. Many heterosexual students may believe that they have never known a gay man or lesbian. (Wright, 1993, p. 29)

The panel that generated this cluster of papers forced me to think (again) about my place in the terrain of the sexual politics of teaching geography. As a straight woman I cannot be one of the "models of gay/lesbian teachers...for both gay/lesbian students and for heterosexual students", but to the extent that I am able, I attempt to provide positive spaces for students who are lesbian, gay or bisexual. Tracey Skelton points out that 'coming out' about our sexual identity to students is "probably one of the biggest dilemmas to face in relation to teaching sexuality and is a unique feature connected with teaching sexuality and geography" (1997, p. 427). When I first began teaching, I actively concealed my sexual identity. I told myself I was pursuing a noble goal, 'closeting' myself in sympathy with lesbians, gays and bisexuals. As a student I had been uncomfortable with what felt like blatant heterosexism from male professors who, at some point during their courses, made (unnecessary) references to their wives. I decided that I would not openly 'flaunt' my heterosexuality in this way. My 'ambiguous' sexual identity meant that I experienced what I consider to be lesbian-baiting and lesbophobic reactions. I have had a few students complain that they do not see how "this stuff is geography" (usually on anonymous student evaluation forms) and I once found a pornographic magazine featuring 'lesbian sex' pushed under my office door.

In recent years I have been troubled by my 'sexual ambiguity' teaching strategy, but not because of anti-lesbian and lesbophobic reactions from (a minority of) students. Rather, I think that my pedagogy may pander to the heterosexual majority (challenging them to address their heterosexism and lesbo/homophobia) at the expense of the lesbian, gay and bisexual students. For example, a few years ago I attended a queer studies conference and met a student who was considering options for graduate school. We talked at length about whether she should go into geography, and whether (and which) departments might be supportive of an out-lesbian studying lesbian geographies. A few months later I ran into another graduate student who had known me for a couple of years. She told me that she had met a woman who was raving about this "great lesbian geographer from Toronto". The second student told me that she felt compelled to both 'out' me to the first student and tell me about the repercussions of my chosen sexual ambiguity. 'Fooling' the first student was an unanticipated consequence of my pedagogy. This experience forced me to question whether I should be projecting an ambiguous sexual identity and 'passing' so well that I even fool lesbians for whom, after all, I claim to provide a positive space (see also, Skelton (1997) and Valentine (1997)).

One conclusion is that I should not teach about marginalised sexualities, given that I do not possess experiential authenticity. However, I worry that abandonment might mean avoiding painful responsibilities. I participate in, and benefit from heterosexual privilege. I try to examine my own location and complicity in the structures of heterosexism and lesbo/homophobia. That leads to an alternative conclusion. As a straight woman, perhaps I would be better positioned teaching about heterosexual hegemony and constructing heterosexuality (which is different from talking about marginalised sexualities). After all, sexuality should not be immediately equated with lesbians, gays and bisexuals. Of 
course, it is much more difficult, perhaps especially for heterosexual feminists, to teach about heterosexual hegemony than about marginalised sexualities. I refer here not merely to my earlier comment about the limited literature that specifically explores the geographies of heterosexuality, but more significantly that I (as a straight woman professor) risk less (although by no means nothing at all) by teaching about marginalised sexualities than I would if I were a lesbian professor. Sexuality (as with other axes of privilege and oppression) is a central organising principle in society. So 'heterosexing' curricula could involve addressing heterosexuality as a political and economic system in which women and men are socially, politically and economically (and to a certain extent, biologically) constructed. By emphasising power relations, these discussions would illustrate how heterosexuals are privileged relative to lesbians, gays and bisexuals, and how straight men are privileged relative to straight women (these sets of relations are, of course, also mediated by other systems of privilege and oppression). Teaching about heterosexual hegemony, while teaching against heterosexism and lesbo/homophobia fits with Janet Wright's (1993) exhortation that "(h)eterosexual faculty members...discuss their own processes in shedding their homophobia. Students desperately need heterosexual models who can honestly discuss their homophobia and their methods for combating it" (1993, p. 31). Hers is a gentle reminder that feminist politics and teaching are not only about exposing power relations, they are also about transforming them.

Correspondence: Kim England, Department of Geography and Program in Planning, University of Toronto, 100 St. George Street, Toronto, ONT M5S 3G3, Canada. Tel: 416 978 1594. Fax: 416978 6729. Email: england@cirque.geog.utoronto.ca

\section{NOTES}

[1] This paper began as a contribution to a panel 'Geographers with sexuality: who and where are we?' organised by Larry Knopp for the AAG meetings in Charlotte, North Carolina in 1996. Ali Grant and Mark Ellis gave me comments on the paper (at very short notice!), and I thank them both.

[2] I tend to use the terms 'sexing' and 'lesbian, gay and bisexual' rather than the increasingly popular 'queering' and 'queer' because I share Sheila Jeffreys' concern that the "appearance of queer theory and queer studies threatens to mean the disappearance of lesbians.... In queer theory and queer studies, lesbians seem to appear only where they can assimilate seamlessly into gay male culture and politics". (1994, p. 459).

[3] For further information about the University of Toronto's Campaign for Positive Space contact: The Status of Women Office, Simcoe Hall, 27 King's College Circle, University of Toronto, Toronto, Ontario, M5S 3G3, Canada.

\section{REFERENCES}

AdLeR, S. \& Brenner, J. (1992) Gender and space: lesbians and gay men in the city, International Journal of Urban and Regional Research, 16, pp. 24-34.

BELL, D. (1991) Insignificant others: lesbian and gay geographers, Area, 24, pp. 409-410.

BeLL, D. (1997) Sex lives and audiotape: geography, sexuality and undergraduate dissertations, Journal of Geography in Higher Education, 21, pp. 411-417.

Bell, D. \& Valentine, G. (1995) Mapping Desire: geographies of sexuality (London, Routledge).

BouthILlETte, A.M. (1994) The role of gay communities in gentrification: a case study of Cabbagetown,

Toronto, in: S. WhitTle (Ed.) The Margins of the City: gay men's urban lives (Ashgate, UK).

Brown, M. (1995) Sex, scale and the 'new urban politics': HIV-prevention strategies from Yaletown, Vancouver, in: D. Bell \& G. Valentine (Eds) Mapping Desire: geographies of sexuality (London, Routledge). 


\section{SYMPOSIUM}

Brown, M.P. (1994) The work of city politics: citizenship through employment in the local response to AIDS, Environment and Planning A, 26, pp. 873-894.

CASTELls, M. (1983) Cultural identity, sexual liberation and urban structure: the gay community in San Francisco, in M. CAstells (Ed.) The City and the Grassroots (Berkeley, University of California Press).

D'Augelli, A.R. (1989) Lesbians' and gay men's experiences of discrimination and harassment in a university community, American Journal of Community Psychology, 17, pp. 317-321.

DAVIS, T. (1995) The diversity of queer politics and the redefinition of sexual identity and community in urban spaces, in: D. Bell \& G. VAlentine (Eds) Mapping Desire: geographies of sexuality (London, Routledge).

DE LAURETIS, T. (1987) Technologies of Gender: essays on theory, film, and fiction (Bloomington, Indiana University Press).

FOREST, B. (1995) West Hollywood as symbol: the significance of place in the construction of a gay identity, Environment and Planning D: Society and Space, 13, pp. 227-252.

GeLTMAKER, T. (1992) The queer nation acts up: health care, politics and sexual diversity in the country of Angels, Environment and Planning D: Society and Space, 10, pp. 609-650.

GRANT, A. (1996) Geographies of oppression and resistance: contesting the reproduction of the heterosexual regime, PhD dissertation, McMaster University.

GRANT, A. (1997) Dyke geographies: all over the place, in: S. ANDERMAHR \& G. GRIFFIN (Eds) Straight Studies Modified: lesbian interventions in the academy (London, Cassell).

JACKSON, P. (1989) Gender and sexuality, in: Maps of Meaning: an introduction to cultural geography (Boston, Unwin Hyman).

JEFFREYS, S. (1994) The queer disappearance of lesbians: sexuality in the academy, Women's Studies International Forum, 17, pp. 459-472.

Johnson, L.C. (1994) What future for feminist geography?, Gender Place and Culture, 1, pp. 103-113.

KNOPP, L. (1990) Some theoretical implications of gay involvement in an urban land market, Political Geography Quarterly, 9, pp. 337-352.

KNopP, L. (1992) Sexuality and the spatial dynamics of capitalism, Environment and Planning D: Society and Space, 10, pp. 651-669.

Knopp, L. (1994) Social justice, sexuality, and the city, Urban Geography, 15, pp. 644-660.

KNopp, L. (1995) Sexuality and urban space: a framework for analysis, in: D. BeLL \& G. VALENTINe (Eds) Mapping Desire: geographies of sexuality (London, Routledge).

LAURIA, M. \& KNOPP, L. (1985) Towards an analysis of the role of gay communities in the urban renaissance, Urban Geography, 6, pp. 152-169.

MCDOweLL, L. (1995) Body work: heterosexual gender performances in city workplaces, in: D. BELL \& G. VAlentine (Eds) Mapping Desire: geographies of sexuality (London, Routledge).

MCDowell, L. \& COURT, G. (1994a) Gender divisions of labour in the post-Fordist economy: the maintenance of occupational sex segregation in the financial services sector, Environment and Planning A, 26, pp. 1397-1418.

MCDowell, L. \& COURT, G. (1994b) Missing subjects: gender, power, and sexuality in merchant banking, Economic Geography, 70, pp. 229-251.

PEAKE, L. (1993) 'Race' and sexuality: challenging the patriarchal structuring of urban social space, Environment and Planning D: Society and Space, 11, pp. 415-432.

RHOADS, R.A. (1994) Coming out in college: the struggle for a queer identity (Westport, CT, Bergin and Garvey).

Rothenberg, T. (1995) 'And she told two friends': lesbians creating urban social space, in: D. Bell \& G. VALENTine (Eds) Mapping Desire: geographies of sexuality (London, Routledge).

Skelton, T. (1997) Issues of sexuality in the teaching space, Journal of Geography in Higher Education, 21, pp. 411-417.

Thrift, N. \& Johnston, R. (1993) The futures of Environment and Planning A, Environment and Planning A, Anniversary Issue, pp. 83-102.

VALENTINE, G. (1993a) Negotiating and managing multiple sexual identities: lesbian time space strategies, Transactions, Institute of British Geographers, 18, pp. 237-248.

VALENTINE, G. (1993b) (Hetero)sexing space: lesbian perceptions and experiences of everyday spaces, Environment and Planning D: Society and Space, 11, pp. 395-413.

VAlentine, G. (1995) Out and about: geographies of lesbian landscapes, International Journal of Urban and Regional Research, 19, pp. 96-111.

VAlentine, G. (1996) (Re)negotiating the 'heterosexual street': lesbian productions of space, in: N. Duncan (Ed.) BodySpace: destablising geographies of gender and sexuality (London, Routledge). 


\section{SYMPOSIUM}

VALENTINE, G. (1997) Ode to a geography teacher: sexuality and the classroom, Journal of Geography in Higher Education, 21, pp. 417-424.

WALKER, L. (1995) More than just skin-deep: fem(me)ininity and the subversion of identity, Gender, Place and Culture, 2, pp. 71-76.

WinCHESTER, H. \& WhITE, P. (1988) The location of marginalised groups in the inner city, Environment and Planning D: Society and Space, 6, pp. 37-54.

WRIGHT, J. (1993) Lesbian instructor comes out: the personal is pedagogy, Feminist Teacher, 7, pp. $26-33$. 